\title{
Molecular differences between human and experimental pancreaticobiliary diversion-induced rat pancreatic neoplasia
}

\author{
P A Hall, N R Lemoine, G Murphy, R H Dowling
}

\begin{abstract}
A series of molecular changes are now known to be seen in human pancreatic neoplasia, including the very frequent mutational activation of Kirsten ras oncogene at codon 12, overexpression of the epidermal growth factor receptor, and abnormalities of c-erbB-2 expression. In order to determine whether similar changes can be seen in animal models of pancreatic cancer a molecular analysis of tumours induced in rats by pancreaticobiliary diversion was performed. The polymerase chain reaction was used to amplify portions of the rat Kirsten ras gene and sequence specific oligonucleotide hybridisation was used to define whether sequences were wild type or mutant. No evidence of mutation was found in the Kirsten ras gene at codons 12 or 61 , where activating mutations are known to occur. In addition immunohistochemical methods were used to investigate expression of $c-e r B-2$ and the epidermal growth factor receptor but no evidence of abnormal expression was found. We conclude that there are major molecular differences between human and experimental rat pancreatic cancer.
\end{abstract}

There is considerable evidence to support the notion that multiple genetic events are necessary for neoplastic transformation ${ }^{12}$ and several complementary molecular abnormalities have been described in human pancreatic cancer. Firstly, the Kirsten ras gene is mutated at codon 12 in up to $90 \%$ of cases. ${ }^{3-8}$ Secondly, the $c-e r b B-$ 2 proto-oncogene, which is closely related in sequence and structure to the epidermal growth factor receptor,,$^{910}$ is overexpressed in at least $20 \%$ of patients. " Thirdly, the epidermal growth factor receptor (c-erbB-1) is abnormally expressed in 30 to $50 \%$ of pancreatic cancers. ${ }^{12} 13$ Finally, there is evidence that the potential ligands for the epidermal growth factor receptor, transforming growth factor $\alpha$, and epidermal growth factor are expressed by pancreatic tumour cells ${ }^{14}$ and thus may form an autocrine loop. ${ }^{15} 16$

Several animal models of pancreatic cancer have been described ${ }^{17}$ In the rat, morphological changes including the progressive formation of hyperplastic nodules, adenomas, and the eventual development of overt malignancy can be induced by treatment with carcinogens such as azaserine. It has previously been reported that pancreaticobiliary diversion can induce hypercholecystokininaemia, pancreatic hyperplasia, and ultimately after 15 to 24 months, neoplasia that is morphologically very similar to that seen in the azaserine model. ${ }^{1820}$ It is not known if the oncogenic events in the animal models resemble those in human pancreatic cancer and consequently we have investigated the pancreaticobiliary diversion model using the polymerase chain reaction and sequence specific oligonucleotide hybridisation to detect mutational activation of the Kirsten ras oncogene and immunohistochemistry to detect abnormalities of expression of the $c$-erbB-2 proto-oncogene and the epidermal growth factor receptor.

\section{Methods}

\section{PANCREATICOBILIARY DIVERSION}

Molecular and immunohistochemical investigations were performed on a previously reported experimental series. ${ }^{1820}$ Pancreaticobiliary diversion was achieved in 24 SPF Wistar rats by the isoperistaltic interposition of $50 \mathrm{~cm}$ of jejunum between the pylorus and ampulla of Vater and material from all animals was subject to molecular and immunohistological examination. The animals were maintained in conventional laboratory conditions and fed a standard rat chow. Animals were killed at 15, 18, 21, and 24 months and pancreatic tissue was snap frozen in liquid nitrogen. Hyperplastic and neoplastic nodules were seen in all 24 test animals but not in any transected control animals $(n=9)$.

\section{IMMUNOHISTOCHEMISTRY}

Immunostaining was performed on $5 \mu \mathrm{m}$ thick cryostat sections using the indirect immunoperoxidase method. A light haematoxylin counterstain was used, after which sections were dehydrated, cleared, and mounted.

The epidermal growth factor receptor was identified by the monoclonal antibody $\mathrm{F} 4$ raised against a synthetic peptide derived from the intracytoplasmic domain (residues 985-996). ${ }^{21}$ The antibody was used at a concentration of $6 \mu \mathrm{g} / \mathrm{ml}$ and was detected by a peroxidase conjugated rabbit anti-mouse (1:50 dilution, Dako UK Ltd). The human squamous carcinoma cell line A431 was used as a positive control and substitution of primary antibody for phosphate buffered saline was used as a negative control.

The $c$-erbB-2 proto-oncogene expression was detected by a polyclonal antibody, $21 \mathrm{~N}$, produced by immunising a rabbit with a synthetic peptide corresponding to amino acid residues 1243 to 1255 of the $C$ terminus of the human $c$ $e r b B-2$ protein. ${ }^{10}$ Affinity purified antibody was used at $2.65 \mu \mathrm{g} / \mathrm{ml}$ and primary antibody was detected with swine anti-rabbit (1:50 dilution; Dako, UK). Positive controls included a mouse 


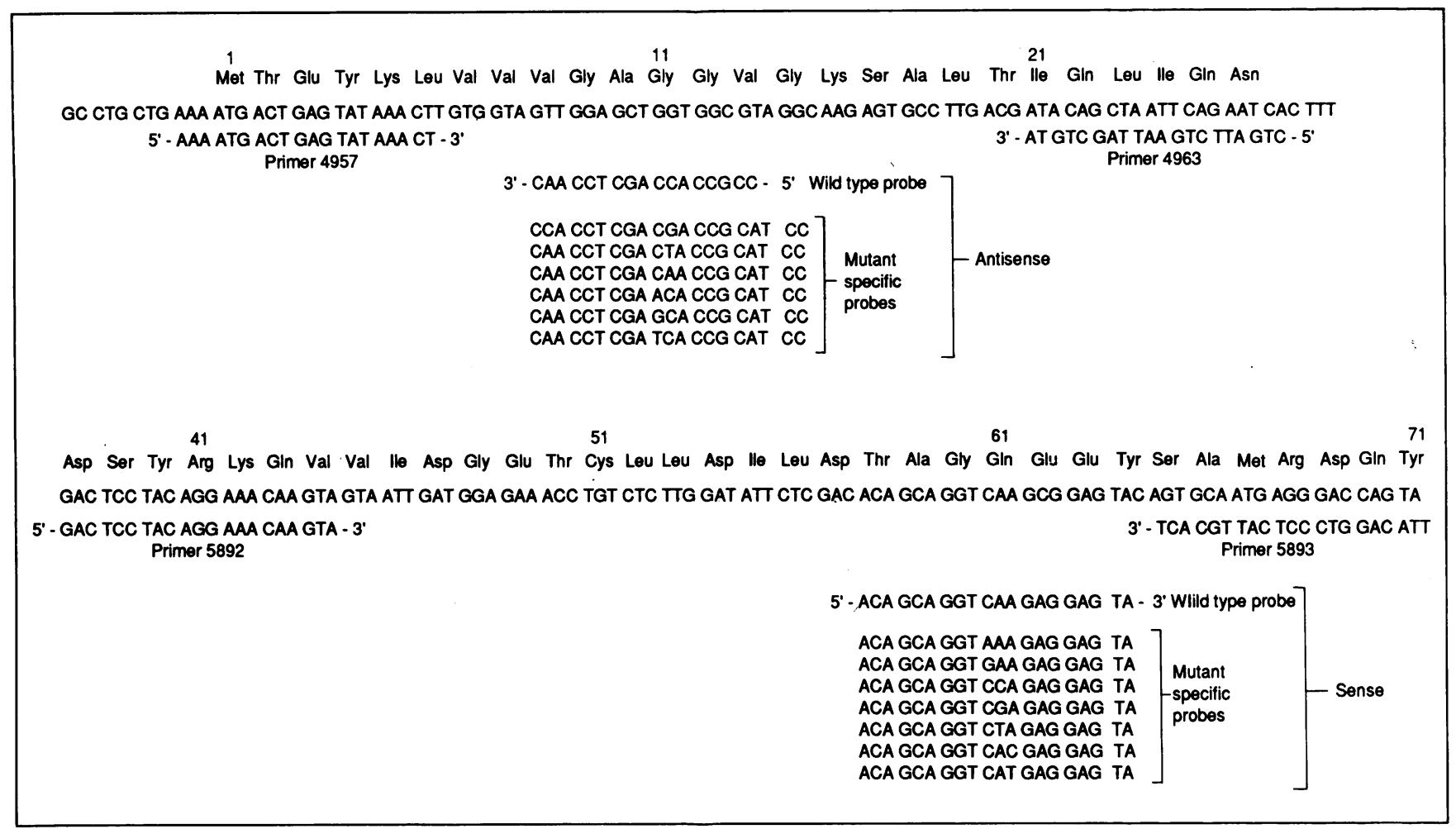

Figure 1: Nucleotide sequence of the rat Ki-ras gene showing amplifying primers 4957 and 4963 for position 12 and 5892 and 5893 for position 61 . Replicate filters were slot blotted with aliquots of the appropriate polymerase chain reaction product and hybridised individually with either 20-mer probes specific for wild type and activating mutants at position 12 or 61 .

fibrosarcoma cell line transfected with an oncogenic neu expressing plasmid, grown as a xenograft and formalin fixed and wax embedded, and cases of breast cancer known to overexpress $c$ $e r b B-2$ as a consequence of gene amplification. Abolition of specific staining by incubation with cognate peptide and substitution of primary antibody with preimmune serum from the same animal were used as negative controls.

\section{POLYMERASE CHAIN REACTION}

The methods for polymerase chain reaction and sequence specific oligonucleotide hybridisation have been described previously. ${ }^{22} 23$ In brief, 10 $\mu \mathrm{m}$ cryostat sections were cut, placed into autoclaved Eppendorf tubes, and contaminating proteins were heat-denatured. A three day proteinase $\mathrm{K}$ digestion was performed. ${ }^{24}$ The resulting material was mixed with appropriate buffer, primers, and Taq polymerase (AmpliTaq, Perkin Elmer-Cetus) and amplified by 30 cycles of denaturation $\left(94^{\circ} \mathrm{C}\right.$, one minute) annealling $\left(60^{\circ} \mathrm{C}\right.$, one minute), and extension $\left(72^{\circ} \mathrm{C}, 1 \cdot 5\right.$ minutes)on a programmable heat block(Techne). The rat specific primers and amplified sequence are shown in Figure 1. These primers and probes were based upon sequences given in Tahira $e t$ al. ${ }^{25}$ Positive control mutants were constructed by the method of Rochlitz et al. ${ }^{26}$

Samples of amplified products were shown to be of the predicted length by agarose gel electrophoresis. Amplified product was applied to nylon filters (Hybond-N, Amersham) with a slot blot apparatus (Millipore). Using the method of Farr et $a l,{ }^{27}$ replicate filters were hybridised individually with each 20-mer oligonucleotide probe specific for either the wild type or mutant rat sequences (shown in Fig 1). Probes were end labelled with $\gamma{ }^{32} \mathrm{P}$ adenosine triphosphate $\left(10^{6}\right.$ counts per $\mathrm{ml}$ of hybridisation buffer) and hybridisation was performed in $3 \mathrm{M}$ tetramethyl ammonium chloride buffer. After washing under stringent conditions $\left(62^{\circ} \mathrm{C}\right.$ for 30 minutes) the filters were autoradiographed at $-70^{\circ} \mathrm{C}$ against Fuji RX film.

\section{Results}

Examination of haematoxylin and eosin stained parallel cryostat sections showed hyperplastic and neoplastic nodules as previously described. ${ }^{1820}$ At 15 months all animals who had undergone pancreaticobiliary diversion had developed hyperplastic nodules, and by 18 months all animals had developed adenomatous lesions.

\section{IMMUNOHISTOCHEMISTRY}

There was no evidence of $c$-erbB-2 or epidermal growth factor receptor immunoreactivity in pancreaticobiliary diversion treated animals or in transection control rats, although both these antibodies are known to recognise the rat proteins $^{1020}$ (and Gullick WJ, personal communication).

\section{POLYMERASE CHAIN REACTION AND} OLIGONUCLEOTIDE HYBRIDISATION

There was no evidence of mutation at position 12 or 61 (where activating mutations might be expected) in the rat Kirsten ras gene since all samples gave strong signals after hybridisation with the wild type probe (Fig 2) and the hybrid showed expected thermal stability. Filters hybridised with mutant probes showed no signal after washing under conditions specific for a 


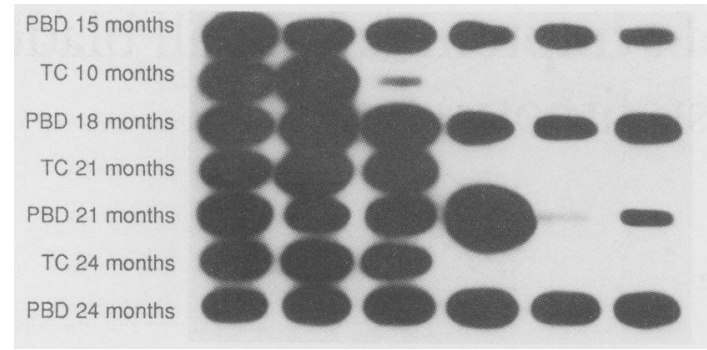

Figure 2: Slot blot analysis of pancreaticobiliary diversion $(P B D)$ induced rat pancreatic neoplasia or transection controls (TC) at 15, 18, 21, and 24 months hybridised with $K i$-ras position 12 wild type probe. After high stringency washing, autoradiography shows wild type probe binding to all $P B D$ and transection control DNA, while no signal was seen with any mutant specific probe. Each slot blot represents analysis of a single animal - that is six PBD animals at each time point and three transection control animals at 18,21, and 24 months.

perfect match. Detection of mutant positive control sequences was possible using these methods.

\section{Discussion}

The results of the studies presented here indicate that the molecular changes known to be present in human pancreatic cancer (Kirsten ras mutated at position 12,c-erbB-2 overexpression, and expression of the epidermal growth factor receptor) are not seen in pancreaticobiliary diversion induced rat pancreatic neoplasia. While pancreaticobiliary diversion is of considerable interest since it represents a model of tumorigenesis not involving carcinogens and in which hypercholecystokininaemia may play an important role, the data presented here suggest that it is not a parallel of human pancreatic neoplasia. This conclusion is supported by the observation, using similar polymerase chain reaction methods, that Kirsten ras is not mutated in rats with pancreatic neoplasia induced by the carcinogen azaserine. ${ }^{27}$

This work was supported by the Imperial Cancer Research Fund. We thank Dr W J Gullick for the gift of the F4 and 21N antibodies, Susan Staddon and David Kellock for technical assistance, and Professor D A Levison for promoting this collaboration.

Presented in part at the British Society of Gastroenterologists Spring meeting, Warwick, March 1990.

1 Weinberg RA. Oncogenes, anti-oncogenes and the molecular basis of multistep carcinogenesis. Cancer Res 1989; 49 3713-21.

2 Land H, Parada LF, Weinberg RA. Tumorigenic conversion of primary embryo fibroblasts requires at least two $\mathrm{CO}^{-}$ operating oncogenes. Nature 1983; 304: 713-18.

3 Almoguera C, Shibata D, Forrester K, Martin J, Arnheim N, Perucho $M$. Most human carcinomas of the exocrine pancreas contain mutant $c-K i$-ras. Cell 1988; 53: 549-54.
4 Smit VTBH, Boot AJM, Smits AMM, Foeuren GJ, Cornelasse CJ, Bos JL. K-ras codon 12 mutations occur very frequently in pancreatic adenocarcinoma. Nucleic Acids Res 1988; 16 : 7773-82.

5 Grunewald K, Lyons J, Frohlich A, et al. High frequency of $\mathrm{Ki}$-ras codon 12 mutations in pancreatic adenocarcinoma. Int f Cancer 1989; 43: 1037-41.

6 Mariyama M, Kishi K, Nakamura K, Obata H, Nishimura S. Frequency and types of point mutation at the 12 th codon of the c-Ki-ras gene found in pancreatic cancers from Japanese patients. Ipn f Cancer Res 1989; 80: 622-6.

7 Gonzales-Cadavid NF, Zhou D, Battifora H, Bar-Eli M, Cline $M J$. Direct sequencing analyses of exon 1 of the c-K-ras gene shows a low frequency of mutations in human pancreatic adenocarcinoma. Oncogene 1989; 4: 1137-40.

8 Shibata D, Almoguera C, Forrester $\mathrm{K}$, et al. Detection of $c-K i$ ras mutations in fine needle aspirates from human pancreatic adenocarcinomas. Cancer Res 1990; 50: 1279-83.

9 Schecter AL, Stern DF, Vaidyanathan L, et al. The neu oncogene: an $e r b B$-related gene encoding a $18500 \mathrm{M}_{\mathrm{r}}$ tumour antigen. Nature 1984; 312: 513-16.

10 Gullick WJ, Berger MS, Bennet PL, Rothbard JB, Waterfield MD. Expression of the c-erbB-2 protein in normal and $M D$. Expression of the c-erbB-2 protein in $n$
transformed cells. Int $f$ Cancer $1987 ; 40: 246-54$.

11 Hall PA, Hughes CM, Staddon SL, Richman PI, Gullick WJ, Lemoine NR. The c-erbB-2 proto-oncogene in human pancreatic cancer. F Pathol 1990; 161: 195-200.

12 Kloppel G, Maillet B, Schewe K, Kalthoff H, Schmiegel WH. Immunocytochemical detection of epidermal growth factor receptors (EGFR) and transferrin receptor (TR) on normal, inflamed and neoplastic pancreatic tissue. Pancreas 1989; 4: 623 (abstract).

13 Yamanaka Y, Onda M, Uchida E, et al. Immunohistochemical study on epidermal growth factor and its receptor in human pancreatic carcinoma. Pancreas 1989; 4:649 (abstract).

14 Barton C, Hall PA, Hughes CM, Lemoine NR. Transforming growth factor $\alpha$ and epidermal growth factor in human pancreatic cancer. F Pathol 1991; 163: 111-6.

15 Smith JJ, Derynck R, Korc M. Production of transforming growth factor- $a$ in human pancreatic cancer cells: Evidence for a superagonist autocrine cycle. Proc Natl Acad Sci USA 1987; 84: 7567-70.

16 Ohmura E, Okada $\mathrm{M}$, Onoda $\mathrm{N}$, et al. Insulin-like growth factors 1 and transforming growth factor $a$ as autocrine growth factors in human pancreatic cancer cell growth. Cancer Res 1990; 50: 103-7.

17 Longnecker DS, Wiebkin P, Schaeffer BK, Roebuck BD. Experimental carcinogenesis in the pancreas. Int Rev Exp Pathol 1984; 26: 177-229.

18 Stace NH, Palmer TJ, Vaja S, Dowling RH. Long term pancreaticobiliary diversion stimulates hyperplastic and adenomatous nodules in the rat pancreas: a new model of spontaneous tumour formation. Gut 1987; 28 (suppl): $265-8$.

19 Miazza BM, Widgren S, Chayvialle JA, Nicolet T, Loizeau E. Exocrine pancreatic nodules after long term pancreaticobiliary diversion in rats. An effect of raised CCK plasma concentrations. Gut 1987; 28 (suppl) 269-74.

20 Palmer TJ, Taylor PR, Mason RC, Murphy GM, Dowling $\mathrm{RH}$. Adenomatous and hyperplastic nodules develop separately after long-term pancreatico-biliary diversion separately after long-term pan
(PBD) in rats. Digestion (in press).

21 Gullick WJ, Marsden JJ, Whittle N, Ward B, Bobrow L, Waterfield MD. Expression of epidermal growth factor receptors on human cervical, ovarian and vulval carcinomas. Cancr Res 1986; 46: 285-92.

22 Lemoine NR, Staddon S, Dickson C, Barnes DM, Gullick WJ. Absence of activating transmembrane mutations in the c-erbB-2 proto-oncogene in human breast cancer. Oncogene 1990; 5: 237-9.

23 Lemoine NR, Mayall ES, Wyllie FS, et al. High frequency of ras oncogene activation in all stages of human tumorigenesis. Oncogene 1989; 4: 159-64.

24 Higuchi R. Simple and rapid preparation of samples for PCR. In: Erlich HA, ed. PCR technology. New York: Stockton In: Erlich HA, ed.

25 Tahira T, Hayashi A, Ochiai M, Tuschida N, Nagayo M, Sugimura T. Mol Cell Biol 1986; 6: 1349-51.

26 Rochlitz CF, Scott GK, Dodson JM, Berry CC. Use of polymerase chain reaction technique to create base-specific ras oncogene mutations. DNA 1988; 7: 515-19.

27 Farr CJ, Saiki RK, Erlich HA, McCormick F, Marshall CJ. Analysis of RAS gene mutations in acute myeloid leukaemia by polymerase chain reaction and oligonucleotide probes. Proc Natl Acad Sci USA 1988; 85: 1629-33.

28 Schaeffer B, Zurlo J, Longnecker DS. Activation of c-K-ras is not detectable in adenomas or adenocarcinomas arising in the rat pancreas. Proc AACR 1990; 31: 133. 